\title{
Vesicles Stage of Camel Brain Development
}

\author{
Etapas del Desarrollo de las Vesículas Cerebrales del Camello
}

Sameh M. Farouk ${ }^{1}$; Said A. Hassan²; Ahmed K. Elsayed ${ }^{2} \&$ Mohamed Abdo $^{3}$

\begin{abstract}
FAROUK, S. M.; HASSAN, S. A.; ELSAYED, A. K. \& ABDO, M. Vesicles stage of camel brain development. Int. J. Morphol., 37(2):498-503, 2019.

SUMMARY: A successive embryonic developmental study was conducted on the brain of twenty eight embryos and fetuses of one humped camel (Camelus Dromedarius), whose crown vertebral rump lengths (CVRL) ranged from 9 to $80 \mathrm{~mm}$, collected from the El-Basateen (Cairo) and Belbees (ElSharqya) Slaughterhouse. The current investigation revealed that camel brain was found to consist of fore, mid and hind brains. The fore brain is divided into telencephalon and diencephalon while the rhombencephalon divided into metencephalon and myelencephalon. Flexures appeared between the vesicles are cervical flexure between the rhomencephalon and the spinal cord, cephalic flexure in the mesencephalon and pontine flexure between the metencephalon, and the myelencephalon of the hind brain (rhombencephalon). The cavity of the rhombencephalon is the fourth ventricle, while that of the diencephalon is the third ventricle, and those of the telencephalon are the lateral ventricles but that of mid brain is the cerebral aqueduct. myelencephalon becomes medulla oblongata and metencephalon developed to pons and cerebellum while mesencephalon gives rise to the cerebral crura and anterior and a posterior colliculus. Diencephalon gives the thalamus, hypothalamus, mamillary body, infundibulum and pineal body while telencephalon becomes the cerebral hemispheres and corpus striatum
\end{abstract}

KEY WORDS: Camel; Embryo; Vesicles; Brain; Development.

\section{INTRODUCTION}

Mammalian brain is the most complex organ of all biological systems (Pakkenberg \& Gundersen, 1997), its developmental stages are protracted processes that begin in the early gestational weeks with the differentiation of the neural progenitor cells and extends at least through late adolescence, arguably throughout the lifespan (Stiles \& Jernigan, 2010). The rostral region of vertebrate neural tubes develops into three morphologically distinct swellings or the primary brain vesicles by differential proliferation of neuroepithelial territories: the forebrain, midbrain, and hind brain (Ishikawa et al., 2012), each of brain vesicles may be composed of several smaller repetitive units known as neuromeres (Nieuwenhuys, 1998). The three primary brain vesicles (forebrain, midbrain, and hindbrain vesicles) subdivided into a series of five secondary brain vesicles (Ishikawa et al.).

At the center of the developing brain, series of interconnected cavities were found to form the ventricular system of the brain which is filled with a fluid called cerebral spinal fluid that is completely recycled several times per day. The ventricular system has a number of important functions including cushioning and protection of the brain, removal of waste material, and transport of hormones and other substances (Brodal, 2010). During brain development, the walls of the ventricles are the site of most neuron production.

Many literatures achieved their research works dealing with prenatal developmental studies of various organs in dromedary camel (Farouk, 2008; Farouk et al., 2012; Osman et al., 2014). The early embryological development of the brain in human and many animals has been reviewed however; no information has been published to date concerning prenatal development of the brain in the one-humped camel. Therefore, the objective of this study was to document the development of brain vesicles stage throughout the early prenatal life in dromedary camel.

\section{MATERIAL AND METHOD}

The current study was carried out on twenty-eight camel embryos and fetuses (their CVRL ranged from 9-80 $\mathrm{mm}$ ) collected from El-Basateen (Cairo) and Belbees

\footnotetext{
${ }^{1}$ Department of Cytology and Histology, Faculty of Veterinary Medicine, Suez Canal University, 41522, Ismailia, Egypt.

${ }^{2}$ Department of Anatomy and Embryology, Faculty of Veterinary Medicine, Suez Canal University, 41522, Ismailia, Egypt.

${ }^{3}$ Anatomy and Embryology Department, Faculty of Veterinary Medicine, University of Sadat City, 32511 Egypt.
} 
(ElSharqya) Slaughter house. The obtained samples were immersed directly into $10 \%$ neutral buffered formalin. Following fixation, the formalin-fixed specimens were then preserved in $70 \%$ ethyl alcohol. The preserved samples were dehydrated using a graded series of ethanol $(75 \%$ up to absolute), subjected to three changes of xylene (I, II, III), then embedded in paraffin wax (melting point $=60^{\circ} \mathrm{C}$ ). The paraffin-moumt specimens were serially sectioned (sagittaly, longitudinally and transversally cut) at $5 \mu \mathrm{m}$ thickness. The paraffin sections were subjected to Harris heamatoxylin and Eosin stain (H\&E) followed the protocols outlined by Bancroft \& Stevens (1996).

The Histological sections were viewed and images were collected with Olympus BX41 research optical photomicroscope equipped with an Olympus DP25 digital camera. The magnification scale bar was reported on the collected photomicrographs.

\section{RESULTS AND DISCUSSION}

The early embryonic stages of camel development at $9 \mathrm{~mm}$ CVRL stage revealed that the cephalic part of the neural tube is markedly expanded and give rise to the main primary brain vesicles. These divisions of the brain can be distinguished through the formation of accommodated flexures and surface folding in its roof and floor. According to our results in Figure 1, there are two main flexures that constitute the primary brain form. The cranial flexure which is ventral and occurs at the level of midbrain (mesencephalon) separating it from the most fore part of brain (prosencephalon) is known as cephalic flexure. The other one, pontine flexure, is a dorsal flexure that bent brain with the convexity facing downward and located in the most

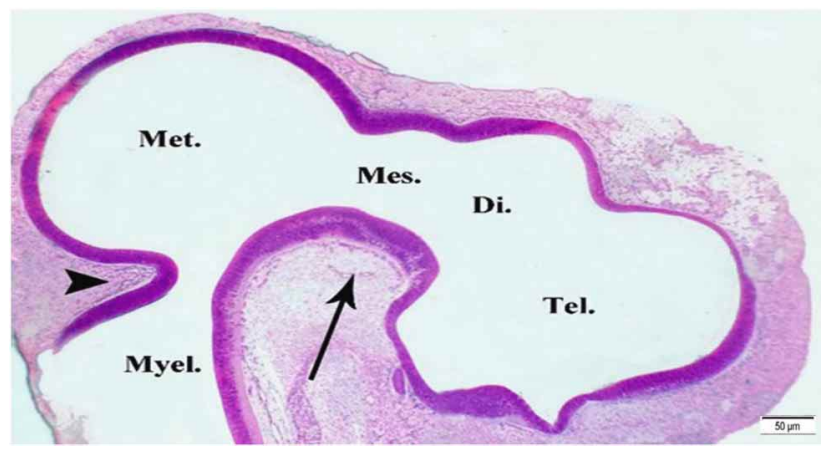

Fig. 1. Photomicrograph of sagittal section of camel embryo (0.9 $\mathrm{cm}$ CVRL) showing the main primary vesicles and flexures. Telencephalon (Tel.), Diencephalon (Di.), Mesencephalon (Mes.), Metencephalon (Met.), Myelencephalon (Myel.), arrow represent the cephalic flexure while the arrowhead represents the pontine flexure. caudal part (hind brain) (rhombecephalon) dividing it into two compartments. In addition to the division of the fore brain into two compartments, these two main flexures configure the brain to be formed from five vesicles. The fore brain gives rise to two divisions; the rostral telencephalon and the caudal diencephalon. Also, the rhombencephalon forms two dilatations as the region caudal to the pontine flexure differentiate into myelencephalon while that rostral to the flexure becomes the metencephalon (Fig. 1).

Each of these brain compartments consists of an outer wall of neural cells enclosing its cavity that named corresponding to its part of brain as follow; Telocaele, diocaele, mesocaele, metacaele, and myelocaele, respectively, which will differentiate later forming the encephalon ventricular system.

These five subdivisions are aligned along the rostralcaudal axis of the embryo and establish the primary organization of the central nervous system (Stiles, 2008). In human, the embryonic patterning affects all brain regions from then forebrain through the spinal column, such that by the end of the embryonic period primitive patterning of sensorimotor regions within the neocortex is established (Bishop et al., 2000), major compartments within diencephalic and midbrain regions have differentiated (Kiecker \& Lumsden, 2004; Nakamura et al., 2005), and the segmental organization of the hindbrain and spinal column have been specified (Gavalas et al., 2003). The cavity of the mesencephalon becomes very narrow forming a narrow duct which known as the cerebral aqueduct (aqueduct of Sylvius) [McGeady et al (2006) in domestic animals and Champney (2016) in human] that connects the third and fourth ventricles (Fig. 2). The lateral ventricles communicate with the third ventricle by a foramen which is called the interventricular foramen (foramen of monro) [McGeady et al. in domestic animals and Champney (2016) in human].

\section{Derivatives and differentiation of the brain subdivisions:}

Myelencephalon: The myelencephalon mainly developed into the medulla oblongata (Fig. 2). Its roof plate appeared as a single layer of neuroepithelial ependymal cells which covered by tela choroidea (vascular mesenchyme and the pia mater). The vascular mesenchyme proliferates and invaginate into the underlying ventricular cavity forming the choroid plexus of the 4th ventricle (posterior choroid plexus). Its cavity (myelocaele) forms the most caudal part of the fourth ventricle (Fig. 2). Same findings were recorded by McGeady et al. in domestic animals and Champney in human.

Metencephalon: Like that were recorded by McGeady et al. in domestic animals and Champney. In human. The 

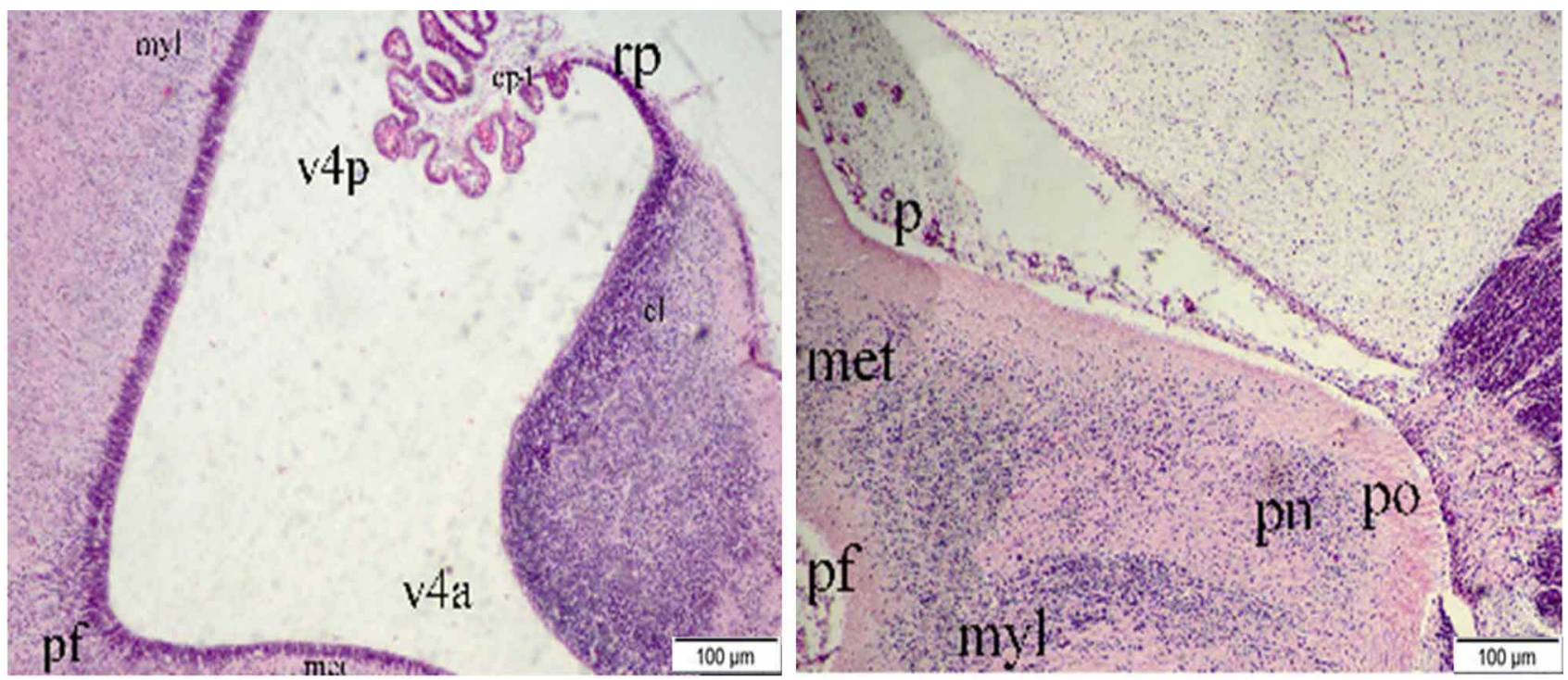

Fig. 2. Photomicrograph of sagittal section of camel embryo (3 cm CVRL) showing; Mylencephalon (Myl), metencephalon (met), pontine flexure (pf), pontine nuclei (pn), pons (po), pia mater (p), anterior part of the $4^{\text {th }}$ ventricle (v4a), posterior part of the $4^{\text {th }}$ ventricle (v4p), roof plate of the mylencehalon (rp), choroid plexus (cp1), developing cerebellum (cl).

current study revealed that the marginal layer of the basal plates of metencephalon in camel embryo undergoes extensive growth ventrally forming a bridge of nerve fibers (pons) that contains the pontine nuclei (Fig. 2). The pontine flexure deepens and the alar plate at the roof of metencephalon proliferate dorsally forming the cerebellar plate which developed to the cerebellum. Its cavity (metacaele) is reduced in size and regarding to formation of the anterior part of the fourth ventricle (Fig. 2).
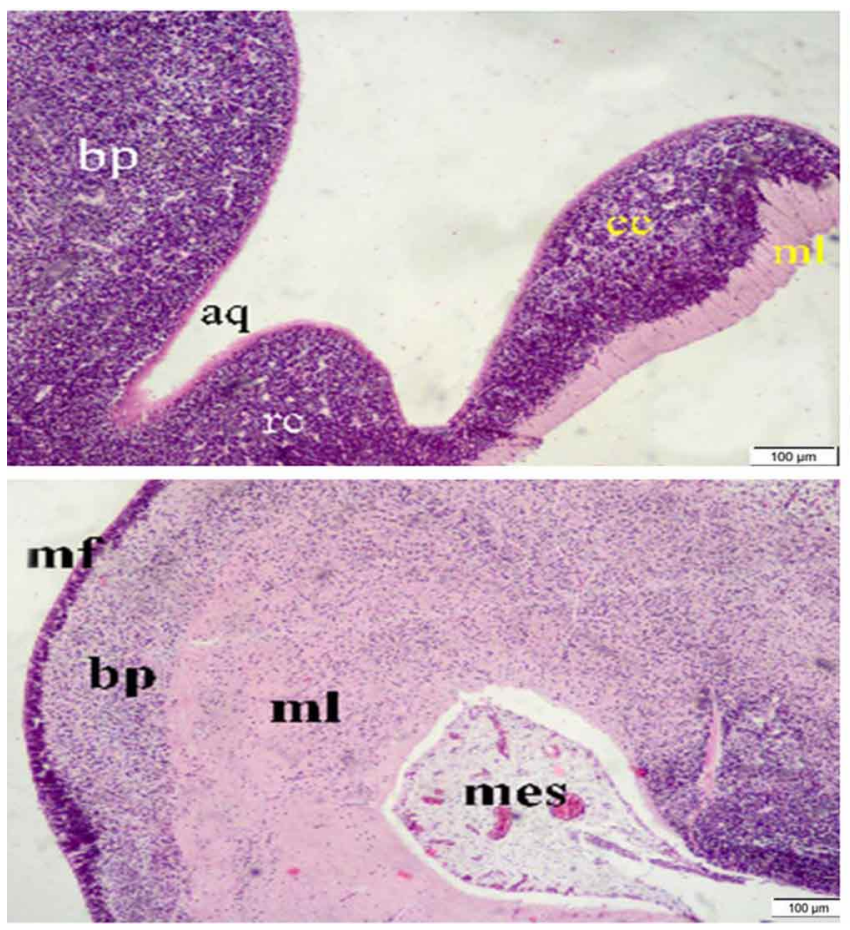

Mesencephalon: The marginal layer of each basal plate of mesencephalon enlarges and thickened forming the cerebral crura or peduncles (crura cerebri) while the alar plates of the mesencephalon give rise to the anterior and posterior colliculus which appear as two longitudinal elevations separated by a shallow midline depression (corpora quadrigemina) (Fig. 3). As the wall of mesencephalon became much thickened, the mesocaele was reduced to a narrow canal called the mesencephalic

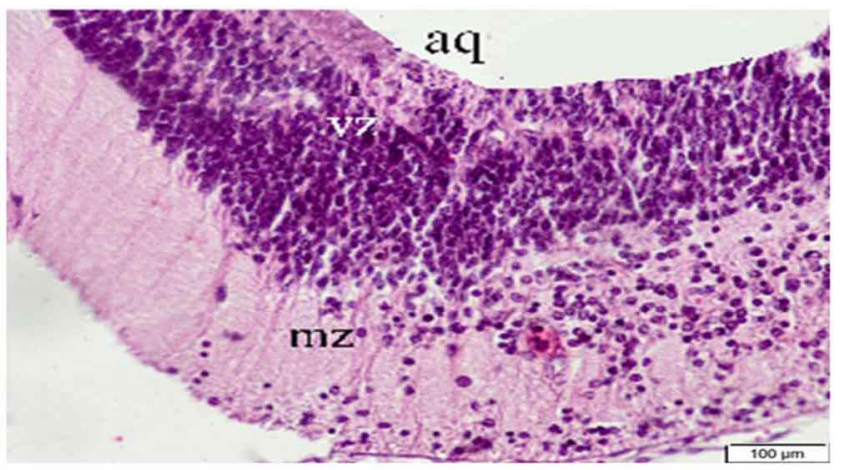

Fig. 3. Photomicrograph of sagittal section of camel embryo (4 cm CVRL) showing; Basal plate (bp), cerebral aqueduct (aq), rostral coliculus (rc), caudal coliculus (cc), marginal layer (ml), ventricular zone (vz), migrating zone $(\mathrm{mz})$. You can recognize the cell migration from the ventricular zone to the outer layers. Mesencephalic flexture (mf), basal plate (bp), marginal layer (ml), mesenchyme (mes). 

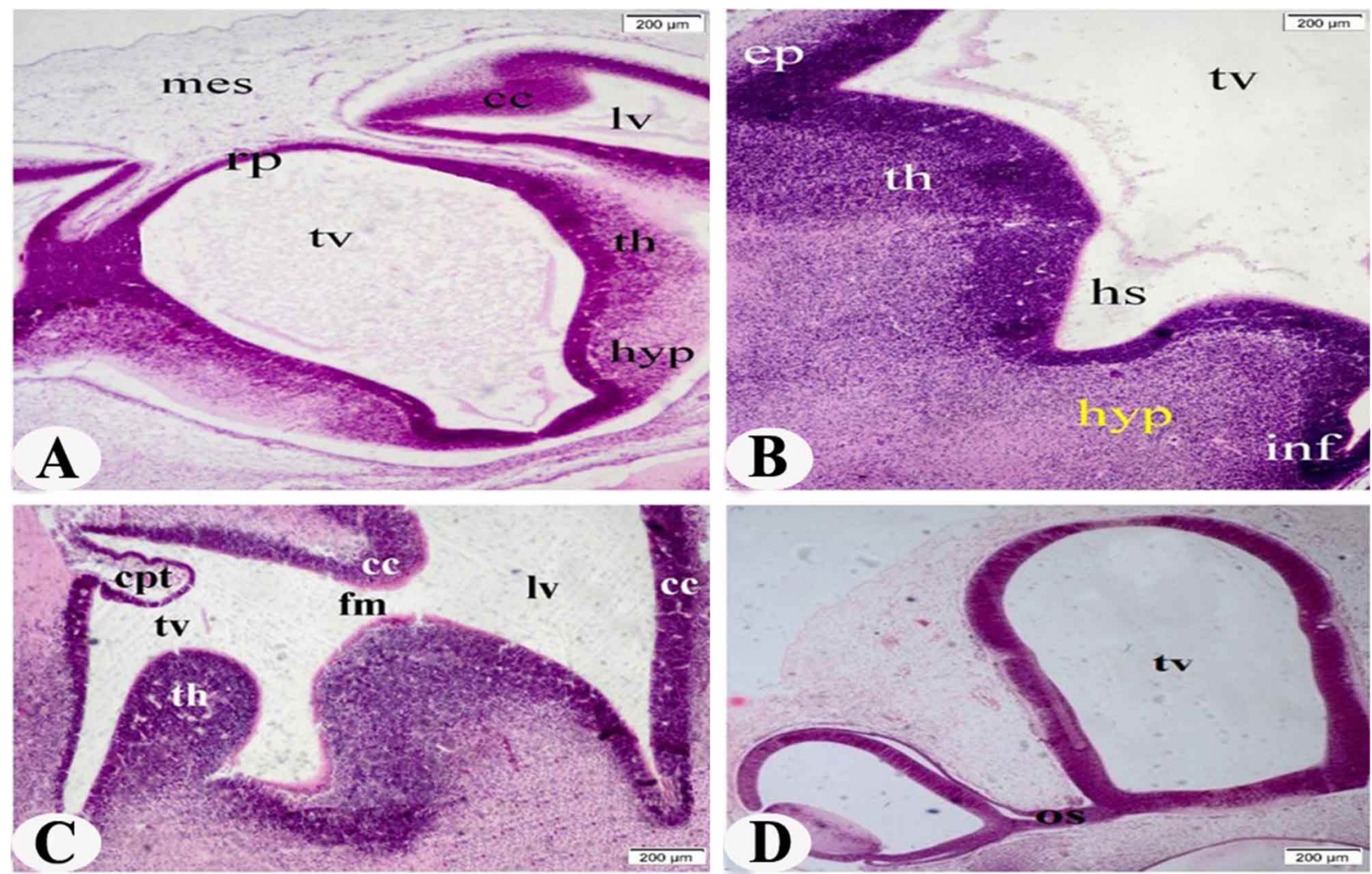

Fig. 4. Photomicrograph of transverse section (A) $(2 \mathrm{~cm}$ CVRL) \& B (3 cm CVRL)) and sagittal section (C) \& (D) (5 cm CVRL) of camel embryo showing; Cerebral cortex (cc), foramen monoro (fm), lateral ventricle (lv), $3^{\text {rd }}$ ventricle (tv), choroid plexus of the $3^{\text {rd }}$ ventricle (cpt), thalamus (th), hypothalamic sulcus (hs), hypothalamus (hyp), epithalamus (ep), infundibulum (inf), mesenchyme (mes), roof plate (rp), and optic stalk (OS).

acquiduct. Such results also had been recorded by same findings were recorded by McGeady et al., in domestic animals and Champney in human. This study declares the cell migration from the ventricular zone to the marginal layer to complete the formation of the corpora quadrigemna (Fig. 3).

Diencephalon: It appears to be consisted of a roof plate and two alar plates and lack the floor and basal plates. The roof plate of the diencephalon appeared thin, formed of a single layer of ependymal cells covered by vascular mesenchyme. Together these layers were pushed into the diocaele inform of a finger like projections and give rise to the choroid plexus of the third ventricle (anterior choroid plexus) (Fig. 4). The alar plates form the lateral walls of the diencephalon which later divided into a dorsal (thalamic) and a ventral (hypothalamic) regions by the hypothalamic sulcus. The thalamus grows projecting gradually into the lumen of the diencephalon till the right and left sides fuse in the midline (Fig. 4). Downward, there is an evagination of the diencephalon, the infundibulum, which gives rise to the stalk and the pars nervosa of the hypophysis. The diocaele cavity formed the third ventricle. At very early stage of development, the optic vesicles arise as outgrowth from the ventrolateral wall of the diencephalon which differentiated latter as optic stalk and optic cup as shown in Figure (4 d). All these findings were on a line with that of Champney in human and McGeady et al., in domestic animals but the later author mentioned a third mass called the epithalamic mass.

Telencephalon: It appeared to be formed of two lateral vesicles (Fig. 5). The cavities of the two vesicles become the lateral ventricles which are connected to the 3rd ventricle by the interventricular foramen (Fig. 4). The telencephalon expands laterally and caudally (Figs. 4 and 5 ). The basal part of the hemispheres grows and bulges into the lumen of the lateral ventricle and into the floor of the interventricular foramen forming the corpus striatum (Fig. 5). At the region where the wall of the hemisphere is attached to the roof of the diencephalon, the wall of the telencephalon is thin, formed of a single layer of ependymal cells covered by vascular mesenchyme, and together they form the choroid plexus of the lateral ventricle (Fig. 4) 


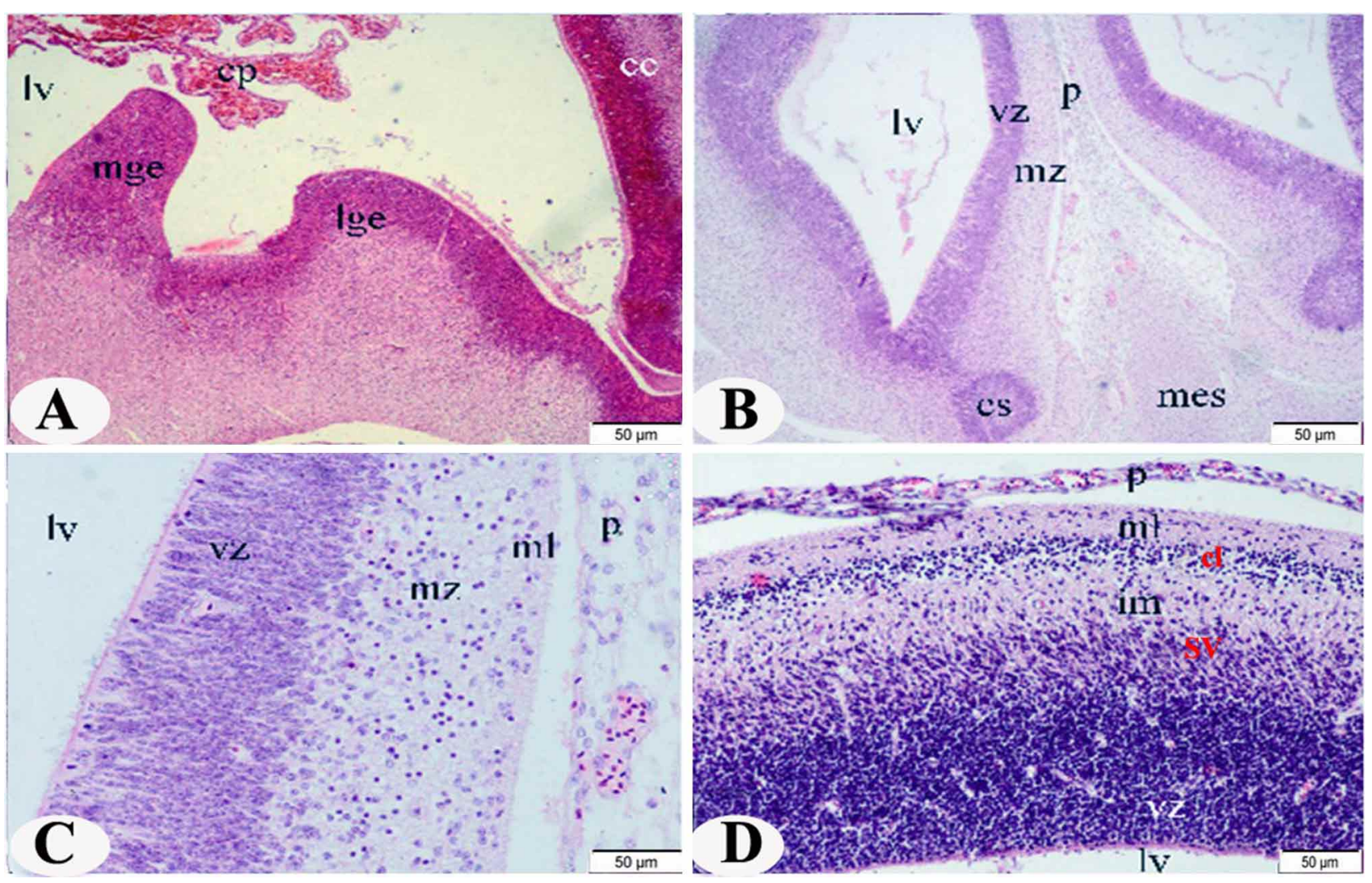

Fig. 5. Photomicrograph of sagittal section (A) and (D) (5 cm CVRL), B (4 cm CVRL), C (1.5 cm CVRL) of camel embryo showing; Cerebral cortex (cc), lateral ventricle (lv), choroid plexus of the lateral ventricle (cp), corpus striatum (cs), medial ganglionic eminence (mge), lateral ganglionic eminence (lge), pia mater (p), migrating zone (mz), ventricular zone (vz), marginal layer (ml), mesenchyme (mes), subventricular zone (sv), intermediate layer (im), cortical layer (cl).

which projects into the lateral ventricle. The telencephalon expands until it covers the lateral aspect of the diencephalon, mesencephalon, and cephalic portion of the metencephalon. The previous results were in accordance with that of Champney in human and McGeady et al. in domestic animals.

Neuron formation and migration: The neurons are produced in the ventricular zone (VZ) and migrate radially from the VZ to the developing cortex which consisted at the early stage, $1.5 \mathrm{~cm}$ CVRL camel embryo, of development from the primitive layers; ventricular, intermediate zone (IZ), and marginal layer (ml) (Fig. 5). As the development proceeds, the brain becomes larger and thicker and the neurons migrate from inner to outer of the wall as shown in Figure 3. At later stage, $5 \mathrm{~cm}$ CVRL camel embryo, this migration of neurons into the developing neocortex resulted in the formation of an orderly 6-layered structure (Fig. 5) which is named as follows; ventricular zone (VZ), sub-ventricular zone (SZ), intermediate zone (IZ), cortical layer (CL), and marginal zone (MZ).
Neuronal migration may occurs by somal translocation that the neurons extend a long basal process attaches to the pial surface, which is the outer surface of the developing brain as that was mentioned by (Miyata $e t$ al., 2001) then the nucleus moves through cytoplasm of the basal process. Another way is called radial glial guide that the nucleus of the radial glial cells remains in the VZ, and the basal process forms a kind of scaffolding along which neurons can migrate (Nadarajah \& Parnavelas, 2002). It has recently been discovered that the cells that provide the scaffolding, are actually the neural progenitor cells (Noctor et al., 2002; Parnavelas et al., 2002; Weissman et al., 2003). The 3rd type of migration is tangential migration in this region, the medial, lateral and caudal ganglionic eminences (Anderson et al., 2001; Nery et al., 2002) that the neurons use a number of guidance molecules produced in local regions along their migratory route to direct their movement into the cortex (Huang, 2009; Valiente \& Marín, 2010). The migration of neurons into the developing neocortex results in the formation of an orderly 6-layered structure like that was reported by Cooper (2008). 
FAROUK, S. M.; HASSAN, S. A.; ELSAYED, A. K. \& ABDO, M. Etapa del desarrollo de las vesículas cerebrales del camello. Int. J. Morphol., 37(2):498-503, 2019.

RESUMEN: Se llevó a cabo un estudio del desarrollo embrionario cerebral de veintiocho embriones y fetos de camello jorobado (Camelus dromedarius). Las muestras fueron recolectadas en los mataderos de El-Basateen (El Cairo) y Belbees (ElSharqya). La investigación reveló que el cerebro de camello posee un cerebro anterior, medio y posterior. El cerebro anterior se divide en telencéfalo y diencéfalo, mientras que el rombencéfalo se divide en metencéfalo y mielencéfalo. Las flexiones encontradas entre las vesículas son la flexión cervical entre el rombencéfalo y la médula espinal; la flexión cefálica en el mesencéfalo; y la flexión pontina entre el metencéfalo y el mielencéfalo del cerebro posterior (rombencéfalo). La cavidad del rombencéfalo conforma el cuarto ventrículo, la del diencéfalo forma el tercer ventrículo, y las del telencéfalo a los ventrículos laterales. En el cerebro medio, la cavidad corresponde al acueducto cerebral. El mielencéfalo se convierte en médula oblonga y el metencéfalo deriva en puente y cerebelo, mientras que el mesencéfalo da lugar a la crura cerebral y a los colículos anterior y posterior. El diencéfalo origina el tálamo, el hipotálamo, el cuerpo mamilar, el infundíbulo y la hipófisis, mientras que del telencéfalo se originan los hemisferios cerebrales y el cuerpo estriado.

PALABRAS CLAVE: Camello; Embrión; Vesículas; Cerebro; Desarrollo.

\section{REFERENCES}

Anderson, S. A.; Marín, O.; Horn, C.; Jennings, K. \& Rubenstein, J. L. Distinct cortical migrations from the medial and lateral ganglionic eminences. Development, 128(3):353-63, 2001.

Bancroft, J. D. \& Stevens, A. Theory and Practice of Histological Techniques. New York, Churchill Livingstone, 1996. pp.184-93.

Bishop, K. M.; Goudreau, G. \& O'Leary, D. D. Regulation of area identity in the mammalian neocortex by Emx 2 and Pax6. Science, 288(5464):344-9, 2000.

Brodal, P. The Central Nervous System: Structure and Function. New York, Oxford University Press, 2010.

Cooper, J. A. A mechanism for inside-out lamination in the neocortex. Trends Neurosci., 31(3):113-9, 2008.

Champney, T. Essential Clinical Neuroanatomy. Hoboken, John Wiley \& Sons Inc, 2016.

Farouk, S. M. Prenatal Development of the Camel's Kidney. M.V.Sc. Thesis. Ismailia, Suez Canal University, 2008.

Farouk, S. M.; Osman, A. H. K. \& Eidaroos, H. Histogenesis of the vagina of the one-humped camel (Camelus dromedarius): morphological evidence of the histochemical aspects. Cell Dev. Biol., 1:105, 2012.

Gavalas, A.; Ruhrberg, C.; Livet, J.; Henderson, C. E. \& Krumlauf, R. Neuronal defects in the hindbrain of Hoxa1, Hoxb1 and Hoxb2 mutants reflect regulatory interactions among these Hox genes. Development, 130(23):5663-79, 2003.

Huang, Z. Molecular regulation of neuronal migration during neocortical development. Mol. Cell. Neurosci., 42(1):11-22, 2009.

Ishikawa, Y.; Yamamoto, N.; Yoshimoto, M. \& Ito, H. The primary brain vesicles revisited: are the three primary vesicles (forebrain/midbrain/ hindbrain) universal in vertebrates? Brain Behav. Evol., 79(2):7583, 2012.

Kiecker, C. \& Lumsden, A. Hedgehog signaling from the ZLI regulates diencephalic regional identity. Nat. Neurosci., 7(11):1242-9, 2004.

McGeady, T. A.; Quinn, P. J.; Fitzpatrick, E. S. \& Ryan, M. T. Veterinary Embryology. Oxford, Blackwell Publishing, 2006.

Miyata, T.; Kawaguchi, A.; Okano, H. \& Ogawa, M. Asymmetric inheritance of radial glial fibers by cortical neurons. Neuron, 31(5):727-41, 2001.

Nadarajah, B. \& Parnavelas, J. G. Modes of neuronal migration in the developing cerebral cortex. Nat. Rev. Neurosci., 3(6):423-32, 2002.

Nakamura, H.; Katahira, T.; Matsunaga, E. \& Sato, T. Isthmus organizer for midbrain and hindbrain development. Brain Res. Brain Res. Rev., 49(2):120-6, 2005.

Nery, S.; Fishell, G. \& Corbin, J. G. The caudal ganglionic eminence is a source of distinct cortical and subcortical cell populations. Nat. Neurosci., 5(12):1279-87, 2002.

Nieuwenhuys, R. Morphogenesis and General Structure. In: Nieuwenhuys, R.; Ten Donkelaar, H. J. \& Nicholson, C. (Eds.). The Central Nervous System of Vertebrates. Berlin, Springer, 1998. pp.159-228.

Noctor, S. C.; Flint, A. C.; Weissman, T. A.; Wong, W. S.; Clinton, B. K. \& Kriegstein, A. R. Dividing precursor cells of the embryonic cortical ventricular zone have morphological and molecular characteristics of radial glia. J. Neurosci., 22(8):3161-73, 2002.

Osman, A. H.; Farouk, S. M.; Eidaroos, H.; Abbott, L. C. \& Ahmed, A. A. Prenatal metanephrogenesis of the camel: morphological evidence of epithelial-mesenchymal interaction. Anat. Histol. Embryol., 43(2):14152,2014

Pakkenberg, B. \& Gundersen, H. J. Neocortical neuron number in humans: effect of sex and age. J. Comp. Neurol., 384(2):312-20, 1997.

Parnavelas, J. G.; Alifragis, P. \& Nadarajah, B. The origin and migration of cortical neurons. Prog. Brain Res., 136:73-80, 2002.

Stiles, J. \& Jernigan, T. L. The basics of brain development. Neuropsychol. Rev., 20(4):327-48, 2010.

Stiles, J. The Fundamentals of Brain Development: Integrating Nature and Nurture. Cambridge, Harvard University Press, 2008.

Valiente, M. \& Marín, O. Neuronal migration mechanisms in development and disease. Curr. Opin. Neurobiol., 20(1):68-78, 2010.

Weissman, T.; Noctor, S. C.; Clinton, B. K.; Honig, L. S. \& Kriegstein, A. R. Neurogenic radial glial cells in reptile, rodent and human: from mitosis to migration. Cereb. Cortex, 13(6):550-9, 2003.

Corresponding author:

Sameh Mohamed Farouk

Faculty of Veterinary Medicine

Suez Canal University

Ismailia

EGYPT

Email: dr_smf_hist@vet.suez.edu.eg dr_smf_hist@yahoo.com

Received: 14-09-2018

Accepted: 21-12-2018 